ISSN = 1980-993X - doi:10.4136/1980-993X
www.agro.unitau.br/ambi-agua
E-mail: ambi-agua@agro.unitau.br
Tel.: (12) 3625-4116

\title{
Retrospective and perspective of Ambiente e Água after one year of publication \\ (doi:10.4136/ambi-agua.15)
}

\section{Getulio Teixeira Batista}

Professor at the Master Degree Program in Environmental Sciences of the University of Taubaté. Estrada Municipal Dr. José Luiz Cembranelli, 5.000; Bairro Itaim; 12.081-010 - Taubaté, SP E-mail: ambi-agua@agro.unitau.br.

\section{RETROSPECTIVE}

After the completion of one year of publication of Ambiente e Água - An Interdisciplinary Journal of Applied Science, the following remarks can be made: three issues were published, totaling 18 articles that involved 68 authors; in addition to three editorials. The articles have come from 24 different institutions from Brazil and abroad. Some of those authors published more than one article. Most of the articles were in Portuguese (60\%), others in English (34\%) and in Spanish (6\%).

Both environmental and water resource themes appeared equally important as the main topic in nine articles each. Five articles covered both themes, simultaneously.

The articles involved local studies (hydrogeology, aquifer recharge) as well as modeling large geographic areas (eight articles) that included the whole Brazilian territory (hydrology modeling), part of the Caribbean region (sea surface temperature and lobster catching), Amazonian Region with four articles (modeling water quality and deforestation), NorthCentral region of Brazil (conservation areas, burning and deforestation), and the Brazilian Southhern region (soybean yield and climatic modeling and forest modeling). Two articles focused on watersheds (physiographic parameters and modeling). One of the articles dealt with permanent preservation areas (PPA) mapping of a municipal district. Another article developed methodology for image analysis that can be used for environmental or water studies.

The main indicator of the scientific community's support was the large number of voluntary peer reviewer's applications. On this first year of publication of Ambi-Água, the list of reviewers included a large number of scientists as can be verified in Table 1 . The journal currently counts with a peer review panel of broad geographic representation and scientific background, even though the great majority is concentrated in the Brazilian Southeastern region, perhaps reflecting the geographic location of the journal.

\section{PERSPECTIVES}

As the journal becomes known by the scientific community at large, it is expected that the number of submissions will increase substantially, especially from abroad. The Editorial Board of Ambi-Água will spread the word about the journal to the Spanish and English speaking communities to increase their participation. The next activities of the Editorial Board will concentrate on seeking broader indexation of the journal to expand the visibility of the articles and seek a positive evaluation by the Qualis/CAPES journal classification system. To reach that goal the Editors will follow Piva et al. (2002) and Ohira et al. (2000) recommendations to overcome the challenges of setting up a new scientific journal. Thus, an increase in the number of published articles in English and Spanish by Ambi-Água is expected to increase the interest in this journal by the international scientific community. 
Table 1. Peer Reviewers of Ambi-Água.

\begin{tabular}{|c|c|c|c|c|}
\hline \multirow{6}{*}{ International } & \multicolumn{3}{|c|}{ Country } & $\mathbf{N}^{\mathbf{o}}$ \\
\hline & \multicolumn{3}{|c|}{ Bolivia } & 1 \\
\hline & \multicolumn{3}{|c|}{ Canada } & 1 \\
\hline & \multicolumn{3}{|c|}{ Spain } & 1 \\
\hline & \multicolumn{3}{|c|}{ United States } & 3 \\
\hline & \multicolumn{3}{|c|}{ United Kingdom } & 1 \\
\hline \multirow{19}{*}{ National } & Region & $\mathbf{N}^{\mathbf{0}}$ & State & $\mathbf{N}^{\mathbf{0}}$ \\
\hline & \multirow{3}{*}{ Center-West } & \multirow{3}{*}{11} & $\mathrm{DF}$ & 6 \\
\hline & & & GO & 2 \\
\hline & & & MS & 3 \\
\hline & \multirow{6}{*}{ Northeast } & \multirow{6}{*}{33} & BA & 2 \\
\hline & & & CE & 7 \\
\hline & & & PB & 12 \\
\hline & & & $\mathrm{PE}$ & 7 \\
\hline & & & RN & 2 \\
\hline & & & SE & 3 \\
\hline & \multirow{3}{*}{ North } & \multirow{3}{*}{14} & AM & 3 \\
\hline & & & PA & 8 \\
\hline & & & TO & 3 \\
\hline & \multirow{3}{*}{ Southeast } & \multirow{3}{*}{167} & MG & 15 \\
\hline & & & RJ & 24 \\
\hline & & & $\mathrm{SP}$ & 127 \\
\hline & \multirow{3}{*}{ South } & \multirow{3}{*}{40} & PR & 11 \\
\hline & & & RS & 20 \\
\hline & & & $\mathrm{SC}$ & 9 \\
\hline
\end{tabular}

\section{FINAL REMARKS}

The first year of a scientific journal that intends to become a reference for quality in its thematic area is very challenging. The lack of history and the absence of indexation subscription limit the number of submissions even if it has been thoroughly announced. Only authors that relate to and trust the editorial board scientific reputation demonstrate confidence in the future of the journal. Therefore, it is anticipated that in the next year of publication, a large number of qualified articles will be submitted. As the journal becomes evaluated by impact and visibility indices, the journal will receive higher recognition and become more commonly considered for article submission. Therefore, registering the journal in new indexation systems is a goal of the Editorial Board of Ambi-Água for the near future.

\section{REFERENCES}

OHIRA, M. L. B.; SOMBRIO, M. L. L. N.; PRADO, N. S. Periódicos brasileiros especializados em biblioteconomia e ciência da informação: evolução. Enc. Bibli: R. Bibliotecon. Ci. Inf., Florianópolis, n. 10, out. 2000. http://www.encontrosbibli.ufsc.br/Edicao_10/lurdinha.htm. Acesso em 20 junho 2007.

PIVA, J. P.; GARCIA, P. C.; BLANK, D. et al. The challenges and the consolidation of a scientific journal. J. Pediatr (Rio J.), ene./feb. 2002, v.78, n.1, p.01-02. ISSN 00217557. 